\title{
INTERPRETASI HAKIM, PENGACARA DAN NOTARIS TERHADAP KONSEP HARTA BERSAMA MENURUT UNDANG-UNDANG NOMOR 1 TAHUN 1974 TENTANG PERKAWINAN DI KABUPATEN BANYUMAS
}

\author{
(Studi Tentang Kriteria yang Digunakan dalam Mengkualifikasi \\ Harta Bersama)* \\ Oleh : \\ Trusto Subekti \\ Fakultas Hukum Universitas Jenderal Soedirman Purwokerto
}

\begin{abstract}
A marriage always have legal consequences, especially in marriage good together. Every regulation of that law have the character of abstraction and passive, hence to comprehend content and intention something section in law have to use appliance is so called interprestasi (interpretation method), result of perception (observasi) whereas studied law and regulation, that is as sources of law. This research have the character of research of law with approach of empirical juridis and research type the used is bibliography (research library) field (field of research) to obtain direct explanation of subjek in this research, that is Judges, Lawyers, and Notaries in Sub-Province of Banyumas. Pursuant to research result obtained from 12 (twelve) method interpretation of which can utilized to comprehend community property concept according to article 35 point (1) Act No.l, 1974, in the reality utilized by all law practitioners, only 2 (two) interpretation method, that is interpretation of language 47 (54,65\%) and systematic interpretation 29 (45,35\%). And result of interpretation inventariasi all practitioners punish to regarding criterion used to determine kualification an object of included in community property from 23 interpretation object item obtained 7 (seven) criterion, as follows: obtained estae during marriage, result of management with diving marriage, production during marriage, earnings during marriage, purchasing during marriage, result of from heritage obtained during marriage, transformation of heritage during marriage. Hence require to be given clear formula pass law and regulation and properly there are same understanding to all practitioners punish to regarding criterion to determine something object of kualification as personal estae or community property, to be society not be bewildered caused by interpretation which different each other.
\end{abstract}

Kata Kunci : Interpretasi, kriteria, konsep harta bersama, hakim pengacara, notaris

\section{A. Pendahuluan}

Keluarga merupakan istilah yang menggambarkan suatu kesatuan kemasyarakatan yang terkecil yang organisasinya didasarkan atas suatu perkawinan yang sah dan idealnya terdiri dari bapak, ibu dan anak-anaknya (nucleus family); jadi keluarga dalam hal ini dikontruksi sebagai keluarga inti. Keluarga dilihat dari sistem sosial merupakan dasar susunan masyarakat Nasional (Basic social Structure).

Sistem sosial menurut Nasikun dikatakan sebagai suatu sistem dari berbagai tindakantindakan, yang terbentuk dari interaksi sosial yang terjadi diantara berbagai individu, yang tumbuh dan berkembang tidak secara kebetulan, melainkan tumbuh dan berkembang di atas standar penilaian umum yang disepakati bersama oleh para anggota masyarakat. Yang paling penting diantara berbagai standar penilaian umum tersebut adalah apa yang kita kenal sebagai norma-norma sosial, dan normanorma sosial tersebut yang sesungguhnya membentuk struktur sosial. ${ }^{1}$

Menurut Parsons dikatakan bahwa suatu masyarakat dapat dilihat sebagai suatu sistem daripada bagian-bagian yang saling berhubungan satu sama lain dan di dalam masyarakat sering terjadi ketegangan-ketegangan yang kadang kala menghasilkan perubahan-perubah-

\footnotetext{
* Artikel ini merupakan hasil penelitian yang dibiayai dengan Anggaran DIPA FH Unsoed 2008.

1 Nasikun, 1986, Sistem sosial Indonesia, Jakarta: CV. Rajawali, hlm. 12-13
} 
Interpretasi Hakim, Pengacara, dan Notaris terhadap 101

Konsep Harta Bersama Menurut UU No. 1 Tahun 1974

an dalam masyarakat, kemudian faktor yang paling penting memiliki daya mengintegrasikan suatu sistem sosial adalah konsensus di antara para anggota masyarakat mengenai nilai-nilai kemasyarakatan tertentu. Sistem nilai tersebut tidak saja merupakan sumber yang menyebabkan berkembangnya integrasi sosial, akan tetapi sekaligus juga merupakan unsur yang menstabilisir sistem sosial itu sendiri. ${ }^{2}$

Kenyataan yang ada dalam masyarakat Indonesia dapat digambarkan sebagai berikut :

1. Masyarakat Indonesia dari Sabang hingga Merauke adalah masyarakat yang sangat heterogin dan terdiri dari banyak sekali suku-suku bangsa.

2. Tipologi masyarakat Indonesia sangat bervariasi (Prismatis), yaitu: Masyarakat Primitif, Masyarakat Sederhana, Masyarakat yang Berburu, meramu, berladang dan bersawah, Masyarakat Pedesaan, Masyarakat Perkotaan, Masyarakat Agraris, Masyarakat Industri, Masyarakat yang ekslusifates dasar budaya maupun agama.

3. Adanya sistem kemasyarakatan (kekerabatan) yang berbeda-beda pada masyarakat di Indonesia (Patrilineal, Matrilineal dan Parental).

4. Masih ada hukum yang berorientasi pada pergolongan rakyat.

5. Masih banyaknya hukum yang berlaku di Indonesia (pluralisme hukum), yaitu sistem Hukum Barat, sistem Hukum Islam dan sistem Hukum Adat.

6. Fenomena mengenai kenyataan masyarakat Indonesia yang sangat heterogin seperti tersebut di atas, dirasa perlu untuk dilakukan suatu perubahan yang mendasar (hakiki), agar dapat dibangun suatu susunan masyarakat (sistem sosial) Indonesia yang bersifat nasional sebagai dasar dari sistem Hukum Nasional yang akan datang. Fungsi hukum disamping sebagai kontrol sosial (fungsi normatif dari hukum), juga merupakan sarana untuk merubah masyarakat (law as a tool of social engineering).

Pembentuk undang-undang telah meng-

\footnotetext{
${ }^{2}$ Ibid. hlm. 11-12
}

konstruksi suatu konsep ide pembaharuan dengan memperkenalkan suatu konsep keluarga yang menjadi tujuan dari perkawinan, dan menurut M. Yahya Harahap bila dibandingkan dengan tujuan perkawinan dengan negaranegara lain yang sudah maju, tujuan perkawinan tersebut jauh lebih tinggi nilai falsafahnya dengan apa yang kita jumpai pada negara-negara yang sudah super modern seperti Amerika pun masih berpendapat bahwa keluarga itu adalah landasan struktur sosial (The family is the basis of our social structure (You and the Law; Arthur P. Crabtree; hal 139) ${ }^{3}$. Famili dianggap sebagai basic social structure, maka Pemerintah harus ikut mengatur ketentuan-ketentuan perkawinan, sehingga legalitas suatu perkawinan ditentukan oleh hukum negara.

Penjelasan mengenai ide pembaharuan di atas menunjukkan bahwa para pembentuk undang-undang telah meletakkan dasar atau basis dari suatu struktur sosial dari sistem sosial Indonesia, yang berorientasi pada sistem keluarga bilateral atau parental. Dipilihnya sistem parental atau bilateral mi dan yang kemudian diberlakukan bagi seluruh masyarakat di Indonesia atau berlaku sebagai unifikasi hukum dengan sendirinya akan berpengaruh terhadap kehidupan masyarakat Indonesia pada umumnya, terutama pada masyarakat yang menggunakan sistem patrilineal dan sistem matrilineal. Penjelasan mengenai unifikasi hukum perkawinan ini akan dimulai dari melihat gambaran politik hvikum perkawinan sebelum dan sesudah berlakunya UU No. 1 Tahun 1974 .

Sebelum berlakunya UU No. 1 Tahun 1974, dalam tatanan hukum di Indonesia sebagai warisan dari sistem hukum kolonial yang berlaku atas dasar pasal $\mathrm{H}$ (telah diamandemen menjadi Pasal I) Aturan Peralihan UUD 1945 (pasal 131 IS jo pasal 163 IS), yaitu:

1. Bagi orang-orang Indonesia asli yang beragama Islam berlaku hukum agama yang telah diresiplir dalam hukum adat.

2. Bagi orang-orang Indonesia asli lainnya ber-

\footnotetext{
3 M. Yahya Harahap, 1975, Hukum Perkawinan Nasional Medan: CV. Zahir Trading Co, hlm. 7
} 
laku hukum adat.

3. Bagi orang-orang Indonesia asli yang beragama Kristen berlaku Huwelijks ordonnantie Cristen Indonesia (S. 1933 Nomor 74).

4. Bagi orang-orang Timur Asing Cina dan warganegara Indonesia keturunan Cina berlaku ketentuan-ketentuan Kitab Undangundang Hukum Perdata dengan sedikit perubahan.

5. Bagi orang-orang Timur Asing lainnya dan warganegara Indonesia keturunan Timur Asing lainnya tersebut berlaku hukum adat mereka.

6. Bagi orang-orang Eropa dan warganegara Indonesia keturunan Eropa dan yang disamakan dengan mereka berlaku Kitab Undang-undang Hukum Perdata.

Peraturan hukum perkawinan sebagaimana disebutkan di atas masih memperlihatkan politik hukum dari pemerintah Hindia Belanda dan di dalamnya memiliki ciri-ciri sebagai berikut :

1. Adanya pergolongan rakyat, pada jaman Pemerintahan Hindia Belanda ada 3 (tiga) golongan Kaula Negara, yaitu: golongan Eropa, golongan Timur Asing Cina dan bukan Cina dan golongan bumi putera.

2. Adanya pluralisme hukum dibidang hukum perkawinan seperti: Kitab Undang-undang Hukum Perdata, $\mathrm{HOCl}$, peraturan Perkawinan Campuran, Hukum Adat dan Hukum Islam yang diresiplir ke dalam Hukum Adat.

3. Pandangan politik hukum pada Jaman Hindia Belanda yang berorientasi pada asas Konkordansi dan terdapat pandangan bahwa dipisahkan antara Hukum Negara dengan Hukum Agama.

4. Pandangan politik hukum Pemerintahan Hindia Belanda yang memandang Hukum Islam sebagai bagian dari Hukum Adat dalam arti Hukum Islam termasuk hukum tidak tertulis, dan berlaku bagi masyarakat Bumi Putera khususnya yang beragama Islam (Teori Receptio in Complexu dan Teori Receptio sebagian).

Setelah Berlakunya UU No. 1 Tahun 1974 Orientasi hukum rangka pembaharuan dan pembangunan Hukum Nasional, adalah:
1. Tidak mengenal pergolongan rakyat.

2. Unifikasi hukum yang artinya hanya ada satu hukum yang berlaku bagi warganegara Indonesia.

3. Adanya pandangan hukum yang mempertimbangkan masuknya hukum agama dalam Hukum Nasional yang dibingkai dalam konsep unifikasi hukum, sehingga terdapat unifikasi akan tetapi juga mewadahi adanya pluralisme di sektor hukum (sahnya perkawinan).

4. Hukum agama, khususnya Hukum Islam mendapatkan legitimasi sebagai hukum positif di Indonesia, dan berlakunya Hukum Islam hams ditafsirkan masih dalam koridor unifikasi hukum.

5. Dalam Hukum Nasional khususnya dalam UU No. 1 Tahun 1974 di dalamnya masih terlihat nuansa hukum yang bersumberkan pada nilai-nilai dan pengertian hukum (begrip) atau konsep dari hukum Islam, Hukum Adat dan KUHPerdata. Hanya dalam hal ini hams diperhatikan bahwa nuansa yang diperkenalkan (introdusir) kepada warganegara harus dipahami dalam suasana unifikasi hukum.

Konsekuensi yuridisnya dari unifikasi hukum bagi warganegara Indonesia adalah tidak ada lagi pluralisme hukum perkawinan dan hanva ada satu hukum perkawinan yang berlaku baginya, yaitu UU No. 1 Tahun 1974. UU No. 1 Tahun 1974 dalam tata hukum Republik Indonesia merupakan hukum negara dan sebagai hukum positif yang berlaku bagi warga negara Indonesia.

Suatu perkawinan selalu memiliki akibat hukum, yaitu mengenai hubungan suami isteri dan harta benda perkawinan. Hubungan suami isteri dalam UU No. 1 Tahun 1974 telah diatur secara tertutup dan bersifat limitatif serta tidak dapat disimpangi, dan mengenai harta benda perkawinan apabila tidak dikecualikan dalam suatu perjanjian perkawinan, kaidah hukumnya bersifat imperatif (memaksa) dengan struktur hartanya terdiri dari harta pribadi suami, harta pribadi isteri dan harta bersama; sehubungan dengan itu melalui Kompilasi Hukum Islam konsep tersebut juga tealah 
Interpretasi Hakim, Pengacara, dan Notaris terhadap 103

Konsep Harta Bersama Menurut UU No. 1 Tahun 1974

diadopsi sebagai struktur harta keluarga dalam keluarga Islam di Indonesia.perlu dikemukakan disini bahwa sebelum berlakunya UU No. 1 Tahun 1974 harta benda perkawinan menurut KUHPerdata (BW) dikenal dengan konsep persatuan bulat harta, dan Hukum Islam lebih memperlihatkan adanya harta pribadi suami dan harta pribadi isteri, selanjutnya menurut Hukum Adat khususnya pada masyarakat dengan sistem kekerabatan parental dikenal konsep harta asal/pribadi suami, harta asal/pribadi isteri dan harta bersama. Dalam penelitian ini difokuskan mengenai harta bersama yang menurut Pasal 35 ayat (1) UU No. 1 Tahun 1974 dirumuskan definisi konsepsionalnya dengan kalimat "Harta benda yang diperoleh selama perkawinan menjadi harta bersama". UU No. 1 Tahun 1974 adalah undangundang pokok dan baru berlaku efektif apabila sudah diterbitkan peraturan pelaksanaannya, sehingga rumusan kaidahnya belum operasional atau belum mengatur secara rinci, atau walau dalam penjelasannya dituliskan "jelas" atau "cukup jelas" tetap saja masih memerlukan penjelasan, atau juga masih memberikan kebebasan yang lebih besar kepada hakim. ${ }^{4}$

Setiap peraturan hukum itu bersifat abstrak dan pasif, maka untuk memahami maksud dan isi sesuatu pasal dalam undangundang hams menggunakan alat yang disebut interpretasi (metode penafsiran) baik dilakukan oleh para hakim maupun oleh ihnuwan. ${ }^{5}$ Interpretasi atau penafsiran merupakan salah satu metode penemuan hukum yang memberi penjelasan mengenai teks undang-undang agar ruang lingkup kaidah dapat ditetapkan sehubungan dengan peristiwa tertentu. Dalam proses deduksi pada waktu menerapan hukum (aktif) pada suatu peristiwa tertentu, yaitu proses bekerjanya hukum obyektif menjadi hukum subyektif (hukum inkonkreto) atau hukum inkasu, diperlukan keahlian (expert) supaya ada kepastian hukum dan diperolehnya keadilan. Yang dimaksud dengan para ahli (expert) yang relevan dengan penerapan kon-

\footnotetext{
${ }^{4}$ Sudikno Mertokusumo, 1999, Mengenai Hukum, Suatu Pengantar, Yogyakarta: Penerbit Liberty, hlm. 153

5 Ibid, hlm 154-155
}

sep hata bersama ini adalah para Hakim, para Pengacara dan para Notaris, karena kepada merekalah oleh hukum diberikan tanggung jawab untuk interpretasi tersebut.

Hasil pengamatan (observasi) sementara dengan mempelajari peraturan perundangundangan, literatur dan beberapa Yurisprudensi Mahkamah Agung Republik Indonesia sebagai sumber-sumber hukum, tidak diperoleh kriteria yang konkrit operasional) yang digunakan untuk mengkualifikasi sesuatu barang termasuk dalam kualifikasi harta bersama. Dalam prinsipnya apabila terdapat suatu hukum dalam kategori interpretable (variasi interpretasi) rnenunjukkan hukum tersebut tidak termasuk hukum yang baik, karena tidak memberikan kepastian hukum, sehingga perlindungan hukum terhadap para pencari keadilan menjadi terabaikan. Hukum berfungsi sebagai perlindungan kepentingan manusia, maka hukum harus dilaksanakan, pelaksanaannya harus normal dan damai atau juga karena pelanggaran; melalui penegakan hukum inilah hukum harus jadi kenyataan, dan dalam penegakan hukum harus diperhatikan kepastian hukum (Rechtssicherheif), kemanfaatan (Zweckmassigkeif) dan keadilan (Gerechtigheiff). ${ }^{6}$

Dalam prakteknya para Hakim, para Pengacara dan para Notaris ketika menghadapi kasus yang menyangkut sengketa harta bersama, mereka berpedoman pada konsep harta bersama yang masih bersifat umum dan abstrak. Tidak adanya kriteria yang jelas yang dapat dipergunakan untuk menentukan sesuatu benda/barang termasuk dalam kualifikasi harta bersama, akan mengakibatkan ketidakpastian hukum, atau akan menimbulkan ketidaktertiban dalam masyarakat, dan akhirnya hukum akan kehilangan fungsinya sebagai pedoman tingkah laku bagi masyarakatnya.

Berdasar atas uraian tersebut di atas, penulis tertarik untuk membahas mengenai metode interpretasi yang dipergunakan para Hakim, para Pengacara dan para Notaris dalam menafsirkan Harta bersama menurut Undang UndangNo. 1 Tahun 1974 dan kriteria yang

\footnotetext{
${ }^{6}$ Ibid, hlm145
} 
104 Jurnal Dinamika Hukum

Vol. 8 No. 2 Mei 2008

dipergunakan oleh para Hakim, para Pengacara dan para Notaris untuk menentukan sesuatu benda/barang termasuk dalam kualifikasi harta bersama.

\section{B. Pembahasan}

1. Metode Interpretasi Yang Dipergunakan Para Hakim, Para Pengacara Dan Para Notaris

Penafsiran dalam ilmu hukum merupakan alat atau metode untuk memahami maksud dan isi sesuatu pasal uandang-undang. Perlu dipahami bahwa sesuatu undang-undang diterbitkan yang kadang kala pasalnya dirumuskan sangat jelas, atau bahkan ada juga yang dirumuskan kurang jelas, bahkan sangat singkat dan dibagian penjelasannya dituliskan sudah jelas atau cukup jelas; padahal sebetulnya masih belum jelas. Apalagi UU No. 1 Tahun 1974 Tentang Perkawinan yang sengaja disusun dalam bentuk undang-undang pokok, yang artinya masih membutuhkan peraturan pelaksanaan sebagai undang-undang organiknya.

Dalam ilmu hukum telah disediakan suatu metode interpretasi agar dalam penerapan

\begin{tabular}{|l|l|c|c|c|c|}
\hline No & $\begin{array}{l}\text { Metode } \\
\text { Penafs. yg } \\
\text { Digunakan }\end{array}$ & $\begin{array}{l}\text { Hakim } \\
\text { Ab (\%) }\end{array}$ & $\begin{array}{l}\text { Peng- } \\
\text { acara } \\
\text { Ab (\%) }\end{array}$ & $\begin{array}{l}\text { Notaris } \\
\text { Ab (\%) }\end{array}$ & $\begin{array}{l}\text { Jlh } \\
\text { Ab (\%) }\end{array}$ \\
\hline 1. & Bahasa & $\begin{array}{c}10 \\
(11,62)\end{array}$ & $\begin{array}{c}22 \\
(25,59)\end{array}$ & $\begin{array}{c}15 \\
(17,44)\end{array}$ & $\begin{array}{c}47 \\
(54,65)\end{array}$ \\
\hline 2. & Sistematis & $\begin{array}{c}8 \\
(9,30)\end{array}$ & $\begin{array}{c}18 \\
(20,93)\end{array}$ & $\begin{array}{c}13 \\
(15,12)\end{array}$ & $\begin{array}{c}39 \\
(45,35)\end{array}$ \\
\hline & Total & $\begin{array}{c}18 \\
(20,92)\end{array}$ & $\begin{array}{c}40 \\
(46,52)\end{array}$ & $\begin{array}{c}28 \\
(32,56)\end{array}$ & $\begin{array}{c}86 \\
(100)\end{array}$ \\
\hline
\end{tabular}

hukumnya dapat diperoleh kejelasan atau kepastian hukum, sebagai berikut:
a. Interpretasi bahasa
b. Interpretasi teleologis/sosiologis
c. hiterpretasi sistematis
d. hiterpretasi historis
e. Interpretasi komparatif
f. Interpretasi futuristis
g. Interpretasi restriktif dan ekstensif
h. Metode argumentasi
i. Argumenteum peranalogiam
j. Penyempitan hukum
k. Argumentum a contrario
l. Penemuan hukum bebas

Penggunaan metode interpretasi tersebut tergantung pada seberapa jauh rumusan sesuatu pasal vindang-undang dipandang dapat memberikan penjelasan bagi pembacanya, terutama bagi seorang ahli hukum. Penafsiran yang sering digunakan pada umumnya adalah penafsiran bahasa atau penafsiran sistematis. Apabila sesuatu pasal sudah dirumuskan secara jelas biasanya digunakan penafsiran bahasa, dan apabila harus menghubung-hubungakan dengan pasal lain dalam undang-undang yang sama atau dengan undang-undang yang lain, maka akan digunakan penafsiran sistematis.

Penafsiran mengenai ketentuan harta bersama sebagaimana disebutkan dalam Pasal 35 ayat (1) UU No. 1 Tahun 1974 yang berbunyi: "Harta benda yang diperoleh selama perkawinan menjadi harta bersama" oleh para praktisi hukum yang dalam hal ini adalah para hakim, para pengacara dan para notaris di Kabupaten Banyumas yang meliputi wilayah hukum pengadilan negeri dan pengadilan agama di Banyumas dan juga di wilayah hukum pengadilan negeri dan pengadilan agama di Purwokerto selanjutnya dapat disajikan dalam bentuk tabel dengan harapan dapat memberikan gambaran mengenai penafsiran yang mereka pergunakan untuk memahami konsep harta bersama sebagaimana dimaksudkan oleh pembentuk undang-undang, sebagai berikut:

Tabel 1

Penafsiran Para Hakim, Para Pengacara dan Para Notaris Terhadap Konsep Harta Bersama Menurut Pasal 35 ayat (1) UU No. 1 Tahun 1974 Sumber: Data Primer yang diolah

Dari 12 (dua belas) metode penafsiran yang dapat dipergunakan untuk memahami konsep harta bersama menurut Pasal 35 ayat (1) UU No. 1 Tahun 1974, ternyata yang dipergunakan oleh para praktisi hukum (hakim, pengacara dan notaris) hanya 2 (dua) metode penafsiran, yaitu penafsiran bahasa $47(54,65 \%)$ dan penafsiran sistematis $29(45,35 \%)$.

Biasanya metode penafsiran bahasa dan penafsiran sistematis banyak digunakan apabila rumusan pasal dipandang telah cukup jelas, apalagi apabila digunakan metode penafsiran bahasa. Adapun perbedaan frekuensi antara 
Interpretasi Hakim, Pengacara, dan Notaris terhadap 105

Konsep Harta Bersama Menurut UU No. 1 Tahun 1974

yang menggunakan penafsiran bahasa dengan penafsiran sistematis ada sebanyak $8(9,30 \%)$, artinya tidak terjadi perbedaan yang mencolok dalam penggunaan metode penafsiran diantara para praktisi hukum, dilihat dari dugunakannya 2 (dua) penafsiran tersebut menunjukkan bahwa mengenai konsep harta bersama menurut Pasal 35 ayat (1) UU No. 1 Tahun 1974 Tentang Perkawinan telah dianggap cukup jelas, terbukti lebih banyak yang menggunakan penafsiran bahasa. Bagi para praktisi hukum yang menggunakan metode penafsiran sistematis diperkirakan karena berpandangan dalam penafsiran tersebut perlu menghubungkan dengan ketentuan lainnya, seperti ketentuan dalam KUHPerdata (BW) yang mengatur mengenai pengertian benda dan ketentuan lainnya mengenai harta benda perkawinan (hanya sayangnya para prakstisi tidak merinci ketentua pasal yang mana yang di-hubungkannya dalam penafsiran sistematis yang dimaksudkan).

2. Kriteria yang Dipergunakan oleh Para Hakim, Para Pengacara dan Para Notaris untuk Menentukan Sesuatu Benda Termasuk dalam Kualifikasi Harta Bersama

Harta benda yang diperoleh suami istri selama perkawinan merupakan harta bersama (Pasal 35 ayat (1) UU No. 1 Tahun 1974), dan harta bawaan masing-masing suami istri dan harta yang diperoleh dari hadiah atau warisan sepanjang tidak ditentukan lain menjadi harta pribadi masing-masing suami istri (Pasal 35 ayat

Tabel 2

Frekuensi Kualiflkasi Sesuatu Harta Termasuk Dalam Harta Pribadi atau Harta Bersama Menurut Para

\begin{tabular}{|l|l|c|c|c|c|c|c|c|c|}
\hline \multicolumn{1}{|c|}{ Obyek } & \multicolumn{2}{|c|}{ Hakim } & \multicolumn{2}{c|}{ Pengacara } & \multicolumn{2}{c|}{ Notaris } & \multicolumn{2}{c|}{ Jumlah } \\
\cline { 3 - 11 } No. & \multicolumn{1}{|c|}{ P } & B & P & B & P & B & P & B \\
\hline 1. & Bendakado/hadiah Perkawinan & 6 & 12 & 22 & 18 & 0 & 28 & 28 & 58 \\
\hline 2. & $\begin{array}{l}\text { Benda hibah ditujukan kepada salah satu } \\
\text { suami/istri }\end{array}$ & 18 & 0 & 40 & 0 & 28 & 0 & 86 & 0 \\
\hline 3. & Benda dari undian yang dimenangkan suami/istri & 2 & 16 & 17 & 23 & 2 & 26 & 21 & 65 \\
\hline 4. & Gaji atau hasil kerja (jualan) dari suami/istri & 0 & 18 & 0 & 40 & 0 & 28 & 0 & 86 \\
\hline 5. & $\begin{array}{l}\text { Deposito/tabungan/uang/saham semasa bujang/ } \\
\text { gadis }\end{array}$ & 18 & 0 & 40 & 0 & 28 & 0 & 86 & 0 \\
\hline 6. & $\begin{array}{l}\text { Bunga/deviden deposito/saham/tabungan semasa } \\
\text { bujang }\end{array}$ & 5 & 13 & 18 & 22 & 16 & 12 & 39 & 47 \\
\hline
\end{tabular}

(2) UU No. 1 Tahun 1974). Dengan demikian struktur harta benda perkawinan menurut UU No, 1 Tahun 1974 terdiri atas harta pribadi masing-masing suami istri dan harta bersama.

Dalam penelitian ini ditentukan obyek penafsiran tentang sesuatu benda perkawinan yang diperoleh suami istri selama perkawinan untuk diberikan kualifikasi termasuk dalam harta pribadi atau harta bersama oleh para hakim, para pengacara dan para notaris di Kabupaten Banyumas, dan obyek penafsiran dimaksud sudah dipertimbangkan mereperesentasikan macam-macam benda yang diperoleh suami isteri selama perkawinan; kemudian disajikan dalam bentuk tabel di bawah ini.

Melihat tabel 2 di atas terdapat hal-hal yang cukup menarik untuk diperhatikan yang dalam hal ini dapat dijadikan 2 (dua) kelompok jawaban, yaitu jawaban yang mutlak dan jawaban yang tidak mutlak, artinya jawabannya masih variatif, sebagai berikut:

a. Kelompok jawaban mutlak $(100 \%)$ terhadap obyek penafsiran ada 3 (tiga) jawaban, yaitu nomor 2 (dua), 4 (empat) dan 5 (lima), yaitu mengenai: deposito/tabungan/uaug/ saham semasa bujang/gadis dikualifikasi sebagaiharta pribadi), benda hibah ditujukan kepada salah satu suami istri dikualifikasi sebagai harta bersama dan gaji atau hasil kerja (jualan) dari suami atau dari istri yang dikualifikasi sebagai harta pribadi.

\section{Hakim, Para Pengacara dan Para Notaris di Kabupaten Banyumas}


106 Jurnal Dinamika Hukum

Vol. 8 No. 2 Mei 2008

\begin{tabular}{|c|c|c|c|c|c|c|c|c|c|}
\hline 7. & $\begin{array}{l}\text { Sawah/kebun/ladang pemberian orang tua } \\
\text { kepada anaknya (suami/ istri) selama perkawinan }\end{array}$ & 12 & 6 & 40 & 0 & 6 & 22 & 58 & 28 \\
\hline 8. & $\begin{array}{l}\text { Hasil panen dari sawah/kebun/ ladang pemberian } \\
\text { orang tua kepada anaknya (suami/istri) selama } \\
\text { perkawinan }\end{array}$ & 2 & 16 & 17 & 23 & 22 & 6 & 41 & 45 \\
\hline 9. & $\begin{array}{l}\text { Uang yang diperoleh dari warisan yang diterima } \\
\text { selama perkawinan }\end{array}$ & 12 & 6 & 40 & 0 & 6 & 22 & 58 & 28 \\
\hline 10. & $\begin{array}{l}\text { Sawah/kebun/ladang (warisan) yang dijual, } \\
\text { kemudian dibelikan rumah/kendaraan }\end{array}$ & 5 & 13 & 4 & 36 & 6 & 22 & 15 & 71 \\
\hline 11. & $\begin{array}{l}\text { Sawah warisan suami yang ditukar tanah kebun } \\
\text { milik istri yang juga dari warisan }\end{array}$ & 12 & 6 & 3 & 37 & 22 & 6 & 37 & 49 \\
\hline 12. & Perusahaan peninggalan orang tua suami & 12 & 6 & 32 & 8 & 28 & 0 & 72 & 14 \\
\hline 13. & $\begin{array}{l}\text { Hasil/keuntungan dari Perusahaan peninggalan } \\
\text { orang tua suami }\end{array}$ & 6 & 12 & 19 & 21 & 12 & 16 & 37 & 49 \\
\hline 14. & $\begin{array}{l}\text { Benda perkakas rumah tangga yang dibeli } \\
\text { suami/istri }\end{array}$ & 0 & 18 & 3 & 37 & 0 & 28 & 3 & 83 \\
\hline 15. & Emas batangan yang dibeli suami/ istri & 0 & 18 & 3 & 37 & 0 & 28 & 3 & 83 \\
\hline 16. & $\begin{array}{l}\text { Perhiasan emas (kalung, cincin, gelang, liontin } \\
\text { yang dibeli suami utk istrinya }\end{array}$ & 2 & 16 & 3 & 37 & 6 & 22 & 11 & 75 \\
\hline 17. & Jam tangan pria yang dibeli suami & 0 & 18 & 4 & 36 & 2 & 26 & 6 & 80 \\
\hline 18. & Jam tangan wanita yang dibeli istri/suami & 0 & 18 & 3 & 37 & 0 & 28 & 3 & 83 \\
\hline 19. & $\begin{array}{l}\text { Mobil/rumah yang dibeli suami dan } \\
\text { diatasnamakan istri }\end{array}$ & 0 & 18 & 4 & 36 & 0 & 28 & 4 & 82 \\
\hline 20. & Mobil yang dibeli suami dan di atas namakan istri & 0 & 18 & 4 & 36 & 2 & 26 & 6 & 80 \\
\hline 21. & Mobil yang dibeli oleh istri pertama & 0 & 18 & 23 & 17 & 14 & 14 & 37 & 49 \\
\hline 22. & Hasil dari sawah istri kedua & 0 & 18 & 17 & 23 & 16 & 12 & 33 & 53 \\
\hline 23. & $\begin{array}{l}\text { Rumah warisan istri pertama dijual untuk beli } \\
\text { mobil }\end{array}$ & 13 & 5 & 40 & 0 & 22 & 6 & 75 & 11 \\
\hline
\end{tabular}

Sumber: data primer yang diolah

b. Kelompok jawaban yang tidak mutlak terhadap obyek penafsiran ada 20 (dua puluh) jawaban, yaitu jawaban nomor 1 (satu), 3 (tiga), 6 (enam) sampai dengan jawaban nomor 23 (dua puluh tiga), yang artinya ada yang telah menafsirkan sebagai harta pribadi atau sebagai harta bersama,

Jawaban mutlak dapat disimpulkan bahwa seluruh praktisi hukum memiliki pemahaman yang sama, berarti ada kepastian hukum kualifikasi harta atas benda yang diperoleh suami istri tersebut, sedangkan adanya jawaban yang tidak mutlak bahkan menunjukkan angka yang besar, yaitu 20 (dua puluh) dari 23 (dua puluh tiga) item benda obyek penafsiran; berarti tidak adanya pemahaman yang sama diantara para praktisi hukum atau dapat dikatakan tidak adanya kepastian hukum mengenai kualifikasi sesuatu benda yang diperoleh suami istri selama perkawinan, berarti pula dapat menjadi rawan konflik (sengketa) diantara suami istri.

Dijelaskan lebih lanjut secara rinci terhadap data atas kelompok jawaban yang tidak mutlak, sebagai berikut:

a. Jawaban nomor 1 (satu) mengenai Benda kado/hadiah perkawinan dengan komposisi sebagai harta pribadi sebanyak 28 (32,56\%) dan sebagai harta bersama sebanyak 58 $(67,44 \%)$. Artinya secara umum para praktisi mengkualifikasi sebagai harta bersama, hanya terhadap yang mengkualifikasi sebagai harta pribadi pada umum dengan alasan privasi, berarti kado dari suami kepada istrinya pada waktu perkawinan dan sebagian lainnya tidak memberikan alasan yang jelas.

b. Jawaban nomor 3 (tiga) mengenai Benda dari undian yang dimenangkan suami atau istri dengan komposisi sebagai harta pribadi sebanyak $21 \quad(24,42 \%)$ dan dikualifikasi sebagai harta bersama sebanyak 65 (75, 
Interpretasi Hakim, Pengacara, dan Notaris terhadap 107

Konsep Harta Bersama Menurut UU No. 1 Tahun 1974

58\%). Artinya secara umum para praktisi mengkualifiukasi sebagai harta bersama, dan yang mengkualifikasi sebagai harta pribadi pada umum dengan alasan yang memperoleh salah satu dari suami istri.

c. Jawaban nomor 6 (enam) mengenai Bunga/ deviden deposito/saham/tabungan semasa bujang dengan komposisi sebagai harta pribadi sebanyak $39(45,35 \%)$ dan dikualifikasi sebagai harta bersama sebanyak 47 (54,65\%). Artinya secara umum para praktisi mengkualifikasi sebagai harta bersama dan yang mengkualifikasi sebagai harta pribadi pada umumnya dengan alasan melekat pada harta pribadi yang dimiliki semasa masih bujang.

d. Jawaban nomor 7 (tujuh) mengenai Sawah/ kebun/ladang pemberian orang tua kepada anaknya (suami/istri) selama perkawinan dengan komposisi sebagai harta pribadi sebanyak $58(67,44 \%))$ sebanyak dan sebagai harta bersama sebanyak 28 (32,56\%). Artinya secara umum para praktisi mengkualifikasi sebagai harta pribadi dan yang mengkualifikasi sebagai harta bersama memberikan alasan pada umumnya karena diperoleh selama perkawinan.

e. Jawaban nomor 8 (delapan) mengenai Hasil panen dari sawah/kebun/ladang pemberian orang tua kepada anaknya (suami/istri) selama perkawinan dengan komposisi sebagai harta pribadi sebanyak 41 (47,67\%) sebanyak dan sebagai harta bersama sebanyak 45 (52,33\%). Artinya secara umum para praktisi mengkualifikasi sebagai harta bersama dan yang mengkualifikasi sebagai harta pribadi memberikan alasan pada umumnya karena masih melekat pada harta yang diperoleh dari warisan.

f. Jawaban nomor 9 (sembilan) mengenai Uang yang diperoleh dari warisan yang diterima selama perkawinan dengan komposisi sebagai harta pribadi sebanyak $58(67,44 \%)$ sebanyak dan sebagai harta bersama sebanyak 28 (32,56\%). Artinya secara umum para praktisi mengkualifikasi sebagai harta pribadi dan yang mengkualifikasi sebagai harta bersama memberikan alasan pada umumnya karena diperoleh selama perkawinan.

g. Jawaban nomor 10 (sepuluh) mengenai Sawah/kebun/ladang (warisan) yang dijual, kemudian dibelikan rumah atau kendaraan dengan komposisi sebagai harta pribadi sebanyak $15(17,44 \%)$ dan sebagai harta bersama sebanyak 71 (82,56\%). Artinya secara umum para praktisi mengkualifikasi sebagai harta harta bersama dan yang mengkualifikasi sebagai harta pribadi memberikan alasan pada umumnya karena masih melekat dengan harta yang diperoleh dari warisan.

h. Jawaban nomor 11 (sebelas) mengenai Sawah warisan suami yang ditukar tanah kebun milik istri yang juga dari warisan dengan komposisi sebagai harta pribadi sebanyak $37(43,02 \%)$ dan sebagai harta bersama sebanyak $49(56,98 \%)$. Artinya secara umum para praktisi mengkualifikasi sebagai harta bersama dan yang mengkualifikasi sebagai harta pribadi memberikan alasan pada umumnya karena masih melekat sebagai harta warisan karena pertukaran.

i. Jawaban nomor 12 (dua belas) mengenai Perusahaan peninggalan orang tua suami dengan komposisi sebagai harta pribadi sebanyak $72(83,72 \%)$ dan sebagai harta bersama sebanyak 14 (16,28\%). Artinya secara umum para praktisi mengkualifikasi sebagai harta pribadi dan yang mengkualifikasi sebagai harta bersama memberikan alasan pada umumnya karena dikelola selama perkawinan.

j. Jawaban nomor 13 (tiga belas) mengenai Hasil atau keuntungan dari perusahaan peninggalan orang tua suami dengan komposisi sebagai harta pribadi sebanyak 37 $(43,02 \%)$ dan sebagai harta bersama sebanyak 49 (56,98\%). Artinya secara umum para praktisi mengkualifikasi sebagai harta bersama dan yang mengkualifikasi sebagai harta pribadi memberikan alasan karena pada umumnya karena masih berkaitan dengan harta peninggalan

k. Jawaban nomor 14 (empat belas) mengenai Benda perkakas rumah tangga yang dibeli oleh suami atau istri dengan komposisi 
sebagai harta pribadi sebanyak $3(3,49 \%)$ dan sebagai harta bersama sebanyak 83 $(96,51 \%)$. Artinya secara umum para praktisi mengkualifikasi sebagai bersama dan yang mengkualifikasi sebagai harta pribadi memberikan alasan pada umumnya karena yang membeli salah satu dari suami istri.

l. Jawaban nomor 15 (lima belas) mengenai Emas batangan yang dibeli suami atau istri dengan komposisi sebagai harta pribadi sebanyak $3(3,49 \%)$ sebanyak dan sebagai harta bersama sebanyak 83 (96,51\%). Artinya secara umum para praktisi mengkualifikasi sebagai bersama dan yang mengkualifikasi sebagai harta pribadi memberikan alasan pada umumnya karena yang membeli salah satu dari suami istri.

m. Jawaban nomor 16 (enam belas) mengenai Perhiasan emas (kalung, cincin, gelang, liontin) yang dibeli suami untuk istrinya dengan komposisi sebagai harta pribadi sebanyak 11 (12,79\%) dan sebagai harta bersama sebanyak 75 (87,21\%). Artinya secara umum para praktisi mengkualifikasi sebagai harta bersama dan yang mengkualifikasi sebagai harta pribadi memberikan alasan pada umumnya karena diberikan untuk istrinya atau ada perlekatan pribadi pemakai.

n. Jawaban nomor 17 (tujuh belas) mengenai Jam tangan pria yang dibeli suami dengan komposisi sebagai harta pribadi sebanyak 6 $(6,98 \%)$ sebanyak dan sebagai harta bersama sebanyak 80 (93,02\%). Artinya secara umum para praktisi mengkualifikasi sebagai harta bersama dan yang mengkualifikasi sebagai harta pribadi memberikan alasan pada umumnya karena terjadi perlekatan sifat dengan pemakai.

o. Jawaban nomor 18 (delapan belas) mengenai Jam tangan wanita yang dibeli istri atau dibelikan suaminya dengan komposisi sebagai harta pribadi sebanyak $3(3,49 \%)$ dan sebagai harta bersama sebanyak 83 $(96,51 \%)$. Artinya secara umum para praktisi mengkualifikasi sebagai harta bersama dan yang mengkualifikasi sebagai harta pribadi memberikan alasan pada umumnya karena ada perlekatan sifat pribadi pemakai.

p. Jawaban nomor 19 (Sembilan belas) mengenai Mobil atau rumah yang dibeli suami dan diatasnamakan istri dengan komposisi sebagai harta pribadi sebanyak $4(4,65 \%)$ dan sebagai harta bersama sebanyak 82 (95,35\%). Artinya secara umum para praktisi mengkualifikasi sebagai harta bersama dan yang mengkualifikasi sebagai harta pribadi memberikan alasan pada umumnya karena sudah diatas namakan istri (pribadi).

q. Jawaban nomor 20 (dua puluh) mengenai Mobil yang dibeli suami dan diatas namakan istri kedua dengan komposisi sebagai harta pribadi sebanyak $6(6,98 \%)$ dan sebagai harta bersama sebanyak 80 (93,02\%). Artinya secara umum para praktisi mengkualifikasi sebagai harta bersama dan yang mengkualifikasi sebagai harta pribadi memberikan alasan pada umunya karena diatas namakan istri kedua atau penghargaan maksud si pemberi/pemilik.

r. Jawaban nomor 21 (dua puluh satu) mengenai Mobil yang dibeli oleh istri pertama dengan komposisi sebagai harta pribadi sebanyak $37(43,02 \%)$ dan sebagai harta bersama sebanyak $49(56,98 \%)$. Artinya secara umum para praktisi mengkualifikasi sebagai harta bersama dan yang mengkualifikasi sebagai harta pribadi memberikan alasan pada umumnya karena dibeli secara pribadi.

s. Jawaban nomor 22 (dua puluh dua) mengenai Hasil dari sawah istri kedua dengan komposisi sebagai harta pribadi sebanyak 33 $(38,37 \%)$ dan sebagai harta bersama sebanyak 53 (61,63\%). Artinya secara umum para praktisi mengkualifikasi sebagai harta bersama dan yang mengkualifikasi sebagai harta pribadi memberikan alasan karena masih terkait dengan harta warisan.

t. Jawaban nomor 23 (dua puluh tiga) mengenai Rumah warisan istri pertama dijual utk beli mobil dengan komposisi sebagai harta pribadi sebanyak $75(87,21 \%)$ dan sebagai harta bersama sebanyak 11 $(12,79 \%)$. Artinya secara umum para praktisi mengkuaiifikasi sebagai harta pribadi dan yang mengkuaiifikasi sebagai harta bersama 
memberikan alasan pada umumnya karena dibelikan mobil selama perkawinan.

Merujuk kembali pada konsep harta benda perkawinan menurut Pasal 35 ayat (1) dan ayat (2) UU No. 1 Tahun 1974 menganut prinsip persatuan harta terbatas, sehingga kelompok harta benda perkawinannya terdiri atas:

a. Harta bersama.

b. Harta pribadi masing-masing suami-isteri, yang dapat dirinci lebih lanjut sebagai berikut:

1) Harta bawaan dan harta hadiah atau warisan suami.

2) Harta bawaan dan harta hadiah atau warisan istri.

Konsep harta bersama dalam undangundang telah dirumuskan definisi konsepsionalnya dengan kalimat "Harta benda yang diperoleh selama perkawinan menjadi harta bersama". Kriterianya, yaitu pada kalimat "...diperoleh selama perkawinan..,", dari kalimat tersebut dapat ditentukan dua kriteria, yaitu "diperoleh" dan "selama perkawinan". kriteria "diperoleh", yang diperoleh suami-istri dengan cara atau dari apapun untuk memperolehnya atau berasal dari mana harta tersebut diperoleh, baik diperoleh oleh suami-isteri secara bersama-sama atau secara sendiri-sendiri.
Kriteria "selama perkawinan", menunjuk waktu atau masa perkawinan yang dimulai sejak saat perkawinan selesai dilangsungkan sampai perkawinan itu putus; dengan catatan tidak termasuk dalam harta bawaan dan harta hadiah atau warisan suami-istri.

Indikator-indikator tersebut diatas masih terasa umum dan belum operasional dan apabila akan diterapkan dalam praktek masih bersifat multi tafsir atau bervariasi tafsirnya. Oleh karena itu diperlukan keahlian atau ketrampilan khusus dalam penerapan hukumnya dalam praktek, dan hal ini menjadi pekerjaan para praktisi hukum, yaitu para hakim, para pengacara dan para notaris.

Para praktisi melakukan kualifikasi terhadap benda obyek penafsiran dan kemudian ditentukan termasuk sebagai harta pribadi $(P)$ atau sebagai harta bersama (B) dalam proses penerapan hukum merupakan proses deduksi dengan menggunakan suatu kriteria tertentu. Kriteria ini merupakan hal yang penting dan lahir melalui suatu proses interpretasi atau penafsiran, hanya sayangnya belum ada ketentuan hukum yang telah mengatur secara rinci mengenai kriteria ini. Maka menjadi penting inventarisasi mengenai kriteria yang digunakan para praktisi.

Tabel 3

Kriteria Untuk Menentukan Sesuatu Benda Termasuk Dalam Harta Pribadi (P) Atau Harta Bersama (B)

\begin{tabular}{|c|c|c|c|c|c|}
\hline No. & Benda obyek penafsiran & $\begin{array}{l}\text { Harta } \\
\text { (P) }\end{array}$ & $\begin{array}{l}\text { Kriteria yang } \\
\text { digunakan }\end{array}$ & $\begin{array}{l}\text { Harta } \\
\text { (B) }\end{array}$ & Kriteria yang digunakan \\
\hline 1. & Bendakado/hadiah Perkawinan & 28 & Privasi & 58 & $\begin{array}{l}\text { Pendapatan selama per- } \\
\text { kawinan }\end{array}$ \\
\hline 2. & $\begin{array}{l}\text { Benda hibah ditujukan kepada salah } \\
\text { satu suami/istri }\end{array}$ & 86 & $\begin{array}{l}\text { Penghargaan thd } \\
\text { pemilik }\end{array}$ & 0 & tdk ada alasan \\
\hline 3. & $\begin{array}{l}\text { Benda dari undian yang dimenangkan } \\
\text { suami/istri }\end{array}$ & 21 & $\begin{array}{l}\text { Yg memperoleh } \\
\text { salah satu dari } \\
\text { suami istri }\end{array}$ & 65 & $\begin{array}{l}\text { Pendapatan selama per- } \\
\text { kawinan }\end{array}$ \\
\hline 4. & $\begin{array}{l}\text { Gaji atau hasil kerja (jualan) dari } \\
\text { suami/istri }\end{array}$ & 0 & Tdk ada alasan & 86 & $\begin{array}{l}\text { Penghasilan selama per- } \\
\text { kawinan }\end{array}$ \\
\hline 5. & $\begin{array}{l}\text { Deposito/tabungan/uang/saham } \\
\text { semasa bujang/gadis }\end{array}$ & 86 & Harta bawaan & 0 & Tdk ada alasan \\
\hline 6. & $\begin{array}{l}\text { Bunga/deviden deposito/saham/ta- } \\
\text { bungan semasa bujang }\end{array}$ & 39 & $\begin{array}{l}\text { Dimiliki semasa ma- } \\
\text { sih bujang }\end{array}$ & 47 & $\begin{array}{l}\text { Pendapatan selama per- } \\
\text { kawinan }\end{array}$ \\
\hline 7. & $\begin{array}{l}\text { Sawah/kebun/ladang pemberian } \\
\text { orang tua kepada anaknya (suami/ } \\
\text { istri) selama perkawinan }\end{array}$ & 58 & $\begin{array}{l}\text { Harta warisan dari } \\
\text { org tua }\end{array}$ & 28 & $\begin{array}{l}\text { Diperoleh selama per- } \\
\text { kawinan }\end{array}$ \\
\hline 8. & $\begin{array}{l}\text { Hasil panen dari sawah/kebun/la- } \\
\text { dang pemberian orang tua kepada } \\
\text { anaknya (suami/istri) selama per- } \\
\text { kawinan }\end{array}$ & 41 & $\begin{array}{l}\text { Melekat pada harta } \\
\text { yg diperoleh dari } \\
\text { warisan }\end{array}$ & 45 & $\begin{array}{l}\text { hasil dari harta warisan } \\
\text { selama perkawinan }\end{array}$ \\
\hline
\end{tabular}


110 Jurnal Dinamika Hukum

Vol. 8 No. 2 Mei 2008

\begin{tabular}{|c|c|c|c|c|c|}
\hline 9. & $\begin{array}{l}\text { Uang yang diperoleh dari warisan } \\
\text { yang diterima selama perkawinan }\end{array}$ & 58 & $\begin{array}{l}\text { Harta warisan dari } \\
\text { org tuanya }\end{array}$ & 28 & $\begin{array}{l}\text { Diperoleh selama per- } \\
\text { kawinan }\end{array}$ \\
\hline 10. & $\begin{array}{l}\text { Sawah/kebun/ladang (warisan) yang } \\
\text { dijual, kemudian dibelikan rumah/ } \\
\text { kendaraan }\end{array}$ & 15 & $\begin{array}{l}\text { Melekat } \\
\text { warisan }\end{array}$ & 71 & $\begin{array}{l}\text { Perubahan bentuk harta } \\
\text { atau karena pembelian }\end{array}$ \\
\hline 11. & $\begin{array}{l}\text { Sawah warisan suami yang ditukar } \\
\text { tanah kebun milik istri yang juga dari } \\
\text { warisan }\end{array}$ & 37 & Karena pertukaran & 49 & Perubahan bentuk harta \\
\hline 12. & $\begin{array}{l}\text { Perusahaan peninggalan orang tua } \\
\text { suami }\end{array}$ & 72 & Harta warisan & 14 & $\begin{array}{lll}\text { Dikelola selama } & \text { per- } \\
\text { kawinan } & & \\
\end{array}$ \\
\hline 13. & $\begin{array}{l}\text { Hasil/keuntungan dari Perusahaan } \\
\text { peninggalan org tua suami }\end{array}$ & 37 & $\begin{array}{l}\text { Berkaitan dengan } \\
\text { harta peninggalan }\end{array}$ & 49 & Hasil dari harta warisan \\
\hline 14. & $\begin{array}{l}\text { Benda perkakas rumah tangga yang } \\
\text { dibeli suami/istri }\end{array}$ & 3 & $\begin{array}{l}\text { Yang membeli salah } \\
\text { satu dari suami istri }\end{array}$ & 83 & $\begin{array}{l}\text { Pembelian untuk rumah } \\
\text { tangga }\end{array}$ \\
\hline 15. & $\begin{array}{l}\text { Emas batangan yang dibeli suami/ } \\
\text { istri }\end{array}$ & 3 & $\begin{array}{l}\text { Yang membeli salah } \\
\text { satu dari suami istri }\end{array}$ & 83 & $\begin{array}{l}\text { Pembelian selama per- } \\
\text { kawinan }\end{array}$ \\
\hline 16. & $\begin{array}{l}\text { Perhiasan emas (kalung, cincin, } \\
\text { gelang, liontin yg dibeli suami untuk } \\
\text { istrinya }\end{array}$ & 11 & $\begin{array}{l}\text { Perlekatan pribadi } \\
\text { pemakai }\end{array}$ & 75 & $\begin{array}{l}\text { Pembelian selama per- } \\
\text { kawinan }\end{array}$ \\
\hline 17. & Jam tangan pria yg dibeli suami & 6 & $\begin{array}{l}\text { Perlekatan sifat dg } \\
\text { pemakai }\end{array}$ & 80 & $\begin{array}{l}\text { Pembelian selama per- } \\
\text { kawinan }\end{array}$ \\
\hline 18. & $\begin{array}{l}\text { Jam tangan wanita yg dibeli } \\
\text { istri/suami }\end{array}$ & 3 & $\begin{array}{l}\text { Ada perlekatan sifat } \\
\text { pribadi pemakai }\end{array}$ & 83 & $\begin{array}{l}\text { Pembelian selama per- } \\
\text { kawinan }\end{array}$ \\
\hline 19. & $\begin{array}{l}\text { Mobil/rumah yg dibeli suami dan } \\
\text { diatasnamakan istri }\end{array}$ & 4 & $\begin{array}{l}\text { Sudah } \\
\text { diatasnamakan istri } \\
\text { (pribadi) }\end{array}$ & 82 & $\begin{array}{l}\text { Pembelian selama per- } \\
\text { kawinan }\end{array}$ \\
\hline 20. & $\begin{array}{l}\text { Mobil yang dibeli suami dan di atas } \\
\text { namakan istri }\end{array}$ & 6 & $\begin{array}{l}\text { Penghargaan mak- } \\
\text { sud si pemberi/pe- } \\
\text { milik }\end{array}$ & 80 & $\begin{array}{l}\text { Pembelian selama per- } \\
\text { kawinan }\end{array}$ \\
\hline 21. & Mobil yg dibeli oleh istri pertama & 37 & Dibeli scr pribadi & 49 & $\begin{array}{l}\text { Pembelian selama per- } \\
\text { kawinan }\end{array}$ \\
\hline 22. & Hasil dari sawah istri kedua & 33 & $\begin{array}{l}\text { Masih terkait } \\
\text { harta warisan }\end{array}$ & 53 & $\begin{array}{l}\text { Harta yang diperoleh } \\
\text { selama perkawinan }\end{array}$ \\
\hline 23. & $\begin{array}{l}\text { Rumah warisan istri pertama dijual } \\
\text { utk beli mobil }\end{array}$ & 75 & $\begin{array}{l}\text { Asalnya dari harta } \\
\text { warisan }\end{array}$ & 11 & $\begin{array}{l}\text { pembelian selama per- } \\
\text { kawinan }\end{array}$ \\
\hline
\end{tabular}

Sumber: data primer yang diolah

Hasil inventarisasi penafsiran para prak-

tisi hukum mengenai kriteria yang digunakan untuk menentukan kualifikasi sesuatu benda termasuk dalam harta bersama sebagaimana tercantum dalam table 5 diatas, dibawah ini disusun secara sistimatis, dari 23 item obyek penafsiran diperoleh 7 (tujuh) kriteria, sebagai berikut:

a. Harta yang diperoleh selama perkawinan

b. Hasil pengelolaan bersama selama perkawinan

c. Penghasilan selama perkawinan

d. Pendapatan selama perkawinan

e. Pembelian selama perkawinan

f. Hasil dari harta warisan diperoleh selama perkawinan

g. Perubahan bentuk harta warisan selama perkawinan

Ke 7 (tujuh) kriteria tersebut diatas dapat diartikan sebagai criteria yang operasional

terhadap definisi konsepsional dari pengertian harta bersama sebagaimana dirumuskan dalam Pasal 35 ayat (1) UU No. 1 Tahun 1974 Tentang Perkawinan. Harapan dari hasil penelitian ini dapat dipergunakan sebagai acuan dalam penerapan hukum pada praktik hukum baik dalam proses peradilan, maupun dalam penyelesaian sengketa di luar pengadilan. Lebih lanjut dapat pula dimanfaatkan oleh para anggota masyarakat yang notabene dalam hal ini menjadi parstisipan dalam penerapan hukum UU No. 1 tahun 1974 Tentang Perkawinan, sehingga kepastian hukum dan keadilan dapat terwujud dan terciptanya tata tertib kehidupan masyarakat pada umumnya.

\section{Penutup \\ 1. Simpulan}

Berdasar hasil analisa dan pembahasan pada Bab IV diatas, dapat ditarik simpulan, 
Konsep Harta Bersama Menurut UU No. 1 Tahun 1974

sebagai berikut:

a. Dari 12 (dua belas) metode penaf-siran yang yang dapat dipergunakan untuk memahami konsep harta bersama menurut Pasal 35 ayat (1) UU No. 1 Tahun 1974, temyata yang dipergunakan oleh para praktisi hukum (hakim, pengacara dan notaris) hanya 2 (dua) metode penafsiran, yaitu penafsiran bahasa $47(54,65 \%)$ dan penafsiran sistematis $29(45,35 \%)$.

b. Hasil inventarisasi penafsiran para praktisi hukum mengenai kriteria yang digunakan untuk menentukan kualifikasi sesuatu benda termasuk dalam harta bersama dari 23 item obyek penafsiran diperoleh 7 (tujuh) kriteria, sebagai berikut:

1) Harta yang diperoleh selama perkawinan

2) Hasil pengelolaan bersama selama perkawinan

3) Penghasilan selama perkawinan

4) Pendapatan selama perkawinan

5) Pembelian selama perkawinan

6) Hasil dari harta warisan diperoleh selama perkawinan

7) Perubahan bentuk harta warisan selama perkawinan

\section{Rekomendasi}

Dari hasil analisa dan pembahasa terhadap data penelitian ini dapat dirumuskan saran-sarannya sebagai beri-kut :

a. Kriteria untuk menentukan sesuatu benda dikualifikasi sebagai harta pribadi atau harta bersama dapat mewujudkan kepastian hukum dan tertib masyarakat, maka perlu di-berikan rumusan yang jelas melalui peraturan perundang-undangan.

b. Seyogyanya terdapat pemahaman yang sama bagi para praktisi hukum mengenai kriteria untuk menentukan sesuatu benda dikualifikasi sebagai harta pribadi atau harta bersama, agar masyarakat tidak dibingungkan karena adanya penafsiran yang berbedapbeda.

Penelitian ini merupakan penelitian yang bersifat inventarisasi hukum, khususnya mengenai suatu kriteria yang dapat dipergunakan untuk mengkualifikasi suatu benda termasuk harta pribadi atau harta bersama, maka hasilnya pun hanya merupakan hasil induksi yang bersifat umum saja dan masih memerlukan klajian yang mendalam. Akhiumya diharapkan dapat membantu memberikan wacana bagi para praktisi hukum, masyarakat dan pembentuk undang-undang dalam melaksanakan posisinya dalam penegakan hukum dan tertib hukum dalam masyarakat yang menjadi tanggung jawab semua pihak.

\section{Daftar Pustaka}

Ardhiwisastra, Yudha Bahkati. 2000. Penafsiran Dan Konstruksi Hukum. Bandung: Alumni;

Departemen Pendidikan Dan Kebudayaan. 2001. Kamus Besar Bahasa Indonesia. Edisi Ketiga. Jakarta: Balai Pustaka:

Harahap, M. Yahya. 1975. Pembahasan Hukum Perkawinan Nasional. Medan: Zahir Trading;

Mertokusumo, Soedikno. 1993. Bab-bab Tentang Penemuan Hukum. Bandung : PT. Citra Aditya Bakti; 1995. Mengenal Hukum, Suatu Pengantar. Yogyakarta: Penerbit Liberty;

Nasikun. 1986. Sistem Sosial Indonesia, Jakarta: CV. Rajawali;

Satrio, J. 1991. Hukum Harta Perkawinan. Bandung: PT. Citra Aditya Bakti;

Sigit, Soehardi. 1992. Pengorganisasian, Yogyakarta: Fakultas Ekonomi Universitas Gadjah Mada; 